Tomasz Sobieraj

\title{
Stefan Żeromski. Tożsamości, poetyki, style odbioru ${ }^{1}$
}

Monografia zbiorowa Stefan Żeromski. Kim byt? Kim jest? - zredagowana przez Zdzisława Jerzego Adamczyka, bodaj najznakomitszego znawcę twórczości pisarza - to jedno z kilku istotnych naukowych pokłosi jubileuszowego roku 2014, w którym środowiska polonistyczne świętowały 15o. rocznicę urodzin autora Przedwiośnia ${ }^{2}$. Praca wyróżnia się - zasadniczo - wysokim poziomem merytorycznym, zróżnicowaniem podjętej tematyki oraz nowatorskim opracowaniem wielu aspektów biografii i twórczości Stefana Żeromskiego.

Pierwszą część monografii tworzy blok artykułów i szkiców poświęconych dziełu pisarza, drugą zaś wypełnia problematyka recepcji.Zlektury całości nasuwają się wnioski ogólne. Otóż wbrew

1 Recenzja książki pod redakcją Zdzisława Jerzego Adamczyka [2015] Stefan Żeromski. Kim byt? Kim jest? Materiaty ogólnopolskiej konferencji naukowej Kielce 2-4 października $2014 r$.

2 Na publikacyjny rezultat rocznicowych przedsięwzięć badawczych złożyły się nadto monografie: Żeromski. Piękno i wolność. Studia [Janicka, Rusek, Czerwiński, red. 2014-2015], Żeromski i inni [Gabryś-Sławińska, Olszewska, red. 2015]. Można by tu jeszcze dodać wartościową książkę autorską Marii Jolanty Olszewskiej [2015] Stefan Żeromski. Spotkania. 
stereotypowym przekonaniom zarówno biografia, jak i twórczość Żeromskiego stanowią ciągle pole atrakcyjne poznawczo, podatne na egzegezy, zakotwiczone również w nowszym instrumentarium badawczym, bądź ukierunkowane w stronę kontekstów dotąd pomijanych. Ileż ciekawych obserwacji odnajdzie tutaj czytelnik zainteresowany na przykład historią edytorstwa dzieł Żeromskiego albo jego warsztatem twórczym! Nowe odkrycia interpretacyjne dotyczą i poetyki dzieł pisarza, i jego poglądów ideowych, i wreszcie związków, jakie łączyły go choćby ze sztuką filmową...

W dotychczasowych ujęciach światopoglądu i twórczości pisarza nie pojawiła się jeszcze kategoria środkowoeuropejskości. Udanie, jak sądzę, zastosował ją Jarosław Ławski, sytuujący autora Przedwiośnia w konstelacji kultury Europy Środkowej. Poglądy ideowe pisarza okazują się bowiem w wielu przypadkach współbieżne z ideami konstytuującymi duchowość środkowoeuropejską. Ławski przekonująco pisze na przykład o projekcie antropologiczno-kulturowym Żeromskiego:

[...] bohaterowie tacy, jak Judym, Siłaczka, doktor Piotr, Bodzanta, należą do wielkiej galerii środkowoeuropejskich społeczników, utopistów, reformatorów, często skazanych na katastrofę w konfrontacji ze światem. U Żeromskiego klęska przychodzi także w wyniku spotkania z własną naturą: ciałem, sumieniem, instynktem. Wydaje się, że polski pisarz dzieli retoryczną egzaltację ideą reformowania świata, symboliką inicjacyjno-odrodzeńczą, z całym pisarskim światem tej części Europy. [Adamczyk, red. 2015: 56]

Nowe kategorie pojęciowo-badawcze wykorzystała do analizy warsztatu twórczego Żeromskiego także Beata Utkowska, która odnalazła elementy „remiksowej” metody pisarza w strukturze Nawracania Judasza, pierwszej części trylogii Walka z szatanem. Na kształt kompozycji oraz struktury narracyjnej tej powieści wpłynęły nie tylko preferencje metodyczne Żeromskiego (choć one z pewnością odegrały tu rolę pierwszoplanową), lecz również jego doświadczenia i perypetie biograficzne, związane z pobytem we Florencji. Utkowska dowiodła, że poetykę immanentną 
Nawracania Judasza współtworzą skomplikowane reguly tekstotwórcze, opierające się na absorpcji cudzego słowa, między innymi z tekstów Georges’a Sorela, Jana Wacława Machajskiego, Émile’a Pougeta, Karola Dębińskiego, Jana Witkiewicza, Aleksandra Brücknera. W rezultacie, jak to zostało przekonująco udowodnione, Nawracanie Judasza stało się swoistą powieścią patchworkową. Zastanawiam się tylko, czy nie byłoby lepiej zrezygnować z finalnego wartościowania metody twórczej pisarza, zastosowanej przezeń w Nawracaniu Judasza. Negatywny sąd o tej powieści [Adamczyk, red. 2015: 74-75] może wszak implikować przywiązanie do normatywnie pojmowanej kompozycji fabularnej...

Dużą wartość merytoryczno-poznawczą mają również dwa studia filmowe. Pierwsze, autorstwa Barbary Leny Gierszewskiej, podejmuje istotny problem badawczy natury interdyscyplinarnej, tj. związków przestrzeni literackiej i filmowej, problem skupiony na filmowym potencjale twórczości literackiej Żeromskiego oraz na poetyce wizualnych - przede wszystkim filmowych, w mniejszym stopniu teatralnych - realizacji dzieł tego pisarza. Autorka kompetentnie przedstawia XX-wieczne dzieje filmowych adaptacji Żeromskiego, jego fascynację sztuką x Muzy, nadto interpretuje filmowe aspekty jego prozy (trafne są zwłaszcza uwagi o „efekcie filmowym" dzieł Żeromskiego [zob. Adamczyk, red. 2015: 111]). Przytaczane tu opinie reżyserów oświetlają ich intencje twórcze, ukazując stosunek do twórczości wielkiego pisarza. Najambitniej odnosił się do niej chyba Andrzej Żuławski, który zamierzał stworzyć film na podstawie Dzienników Żeromskiego, jednak zrealizował wyłącznie - udany zresztą - krótki obraz Pavoncello.

Z kolei drugie studium filmowe stanowi szkic Moniki Gabryś-Sławińskiej zatytułowany Stefana Żeromskiego otwieranie się na kulturę popularna - scenariusz filmowy „Wieczna fala”. Autorka swobodnie i z dużą kompetencją porusza się po terytorium historii sztuki filmowej, barwnie opisując jej początki na ziemiach polskich. Rola Żeromskiego w rozwoju tej sztuki okazuje się niebagatelna. Scenariusz Wiecznej fali odznacza się wieloma walorami artystycznymi; jest napisany nie bez wyczucia konwencji - rozwijającej się wtedy coraz gwałtowniej - nowej sztuki. Przekonująco wypada w studium rekonstrukcja tych cech wyobraźni artystycznej pisarza, które jesz- 
cze przed napisaniem przezeń scenariusza Wiecznejfali wykazywały już potencjał filmowy - przykładem są Zapiski z podróży.

W pierwszej części monografii wartościowych cząstek jest niemało. Na uwagę zasługują między innymi: praca Beaty K. Obsulewicz, poświęcona semantyce przestrzeni ogrodów w twórczości Żeromskiego; artykuł Marii Jolanty Olszewskiej, Wiatry, wichry i wiaterki... O możliwościach ekspresyjnych języka Stefana Żeromskiego, zawierający skrupulatną analizę stylistyki historycznej oraz poetyki powieści Żeromskiego, oparty na zasadnej hipotezie ścisłego związku między jego przekonaniami natury filozoficznej (ontologicznymi i epistemologicznymi) a zasadą konstruowania przezeń literackich obrazów świata; komparatystyczny artykuł Aleksandry Budrewicz, Rywal Dickensa? Stefana Żeromskiego lektury prozy Dickensa, przynoszący wnikliwą analizę utworów obu pisarzy, skupioną choćby na zjawisku „fizjologii” wielkiego miasta, świetnie portretowanej i przez Żeromskiego, i przez Dickensa (intrygująco brzmi w artykule metafora „powieść wilgotna”, odniesiona przez badaczkę do Ludzi bezdomnych Żeromskiego oraz do Samotni i Naszego wspólnego przyjaciela Dickensa); studium Krzysztofa Jaworskiego, Stefan Żeromski wobec nowych kierunków literackich na progu niepodległości - ze szczególnym uwzględnieniem futuryzmu, skupione na analizie stosunku pisarza do zjawiska awangard literackich w Polsce po odzyskaniu niepodległości, formułujące hipotezę, według której problem futuryzmu Żeromski konsekwentnie rozpatrywał w kontekście kultury narodowej oraz jej przyszłości, motywując swoją niechęć do tego prądu głębokim przekonaniem o konieczności obrony „tkanki” literatury polskiej, która własną innowacyjność powinna realizować na innych zasadach; wreszcie artykuł Grażyny Legutko, „Stużący światła”. O „Promieniu” Stefana Żeromskiego raz jeszcze, poświęcony między innymi wnikliwej egzegezie parabolicznego czy też moralitetowego wymiaru fabuły, przejawiającego się choćby w tym, że - jak przekonuje autorka - powieść „można [...] czytać jako przypowieść o ziemskim piekle i świecie, w którym najważniejszy jest duchowy wymiar człowieka" [Adamczyk, red. 2015: 269].

W drugiej, recepcyjnej części monografii również znalazło się sporo interesujących, a niekiedy odkrywczych prac. Jedną z nich 
jest studium Bogdana Mazana, Kim był Stefan Żeromski dla Posta Prawdy?, podejmujące problem skomplikowanych relacji wzajemnych między Świętochowskim a Żeromskim. Przynosi ono kilka bardzo interesujących hipotez w zakresie krytycznoliterackiej recepcji twórczości Żeromskiego przejawiającej się w pismach Posła Prawdy. Zarazem autor zarysowuje relację odwrotną: stosunek Żeromskiego do Świętochowskiego, naznaczony wieloma tonami emocjonalnymi, zasadniczo jednak aprobatywny, bo w znacznej części wynikający przecież z ideowych podobieństw między tymi pisarzami.

W szkicu $W$ 1oo-lecie urodzin Żeromskiego. Głos z emigracji Violetta Wejs-Milewska podjęła istotny problem badawczy: mianowicie zagadnienie wpływu Żeromskiego jako pisarza i jednego z duchowych przywódców narodu na twórców emigracyjnych, którzy z okazji stulecia urodzin artysty odpowiedzieli na ankietę Radia Wolna Europa. Odpowiedzi te ułożyły się w bardzo interesującą konstelację głosów zróżnicowanych i wcale niejednoznacznych; obok entuzjastycznej opinii Kazimierza Wierzyńskiego można postawić krytyczny stosunek do Żeromskiego, wyrażony choćby przez Gustawa Herlinga-Grudzińskiego i Witolda Gombrowicza. Znamienne przy tym, że na przykład Wierzyński, powołując się na ideowo-etyczny patronat autora Ludzi bezdomnych, kładł silny akcent na trwałość tradycji duchowej polskiego romantyzmu, przejawiającej się w idei służebności literatury.

W artykule Boje Stanistawa Pigonia o petne wydanie utworów Stefana Żeromskiego Adamczyk odkrywa z kolei nieznane dotąd bliżej perypetie wydawnicze edycji pism Żeromskiego, przygotowywanych od początku lat 5o. ubieglego wieku przez prof. Stanisława Pigonia. Porządek wywodu układa się tutaj momentami w pasjonującą historię patologii życia kulturalnego w PRL-u, z którymi przyszło się zmagać zasłużonemu edytorowi Żeromskiego. Przeszkody polityczne były przez lata zaporą uniemożliwiającą wydanie „niecenzuralnych” utworów pisarza. Korespondencja Pigonia, stanowiąca główny przedmiot prowadzonych w tekście analiz, oświetla z jednej strony patologie systemu totalitarnego, który paraliżował projekty wydawnicze w Polsce, z drugiej zaś wręcz heroiczną postawę wielkiego polskiego literaturoznawcy, walczącego z bezdusznością aparatu cenzury państwowej. 
Chiazm Żeromskiego: od niepoczytalnej popularności do niepopularnej niepoczytności to z kolei błyskotliwy, przesycony nutą wyrafinowanej (auto)ironii i gorzkiej zadumy nad współczesnością esej naukowy Jerzego Paszka, napisany przez zasłużonego badacza i edytora dzieł Żeromskiego. Autor w syntetycznym skrócie oddaje zmienne koleje recepcji twórczości pisarza, kładąc akcent na współczesną „niepopularną niepoczytność, która tę twórczość ogarnia. Mimo lekkiego tonu tekst ten zawiera obserwacje istotne i skłaniające do namysłu nad stanem dyscypliny, rozwojem „żeromskologii” oraz losem przedsięwzięć edytorskich na jej niwie podejmowanych. Autor zwraca między innymi uwagę na konieczność skrupulatnej i dociekliwej analizy tekstologicznej, która, niestety, w wielu przypadkach zawodziła (vide: Popioły), co wynika chyba z zasadniczych a negatywnych przemian, jakie dotykają literaturoznawstwo polskie.

Monografię poszerzono o część zawierającą panel dyskusyjny. Zamieszczone w niej teksty skoncentrowały się przede wszystkim wokół miejsca Żeromskiego w kulturze współczesnej oraz podnosiły kwestię niegdysiejszych oraz obecnych dyskusji nad duchową tożsamością pisarza. Grażyna Borkowska określiła idiom psychiki Żeromskiego jako przykład resentymentu, którego istotą było nieustanne i niedające się wyprzeć pragnienie: „[... ] rozdrapać rany, by nie mogły się zabliźnić, wstrząsnąć sumieniami, pobudzić do działania” [Adamczyk, red. 2015: 430]. Badaczka nie sformułowała jednoznacznej opinii o ewentualnej aktualności dorobku Żeromskiego; postawiła pytania otwarte, zastanawiała się na przykład nad tym, czy współcześnie nie pozostanie żywa empatia pisarza z „wykluczonymi”. Z kolei dla Andrzeja Mencwela istotny, jak się zdaje, jest podnoszony przez autora Przedwiośnia imperatyw moralny jako warunek reform społecznych, a także idea społeczeństwa stowarzyszeniowego, w którym obywatele byliby wolnymi, aktywnymi i świadomymi członkami wspólnoty [por. Adamczyk, red. 2015: 435]. Nuta nostalgii wybrzmiewa z wypowiedzi Adamczyka; uczony, podnosząc niekwestionowaną niegdyś pozycję Żeromskiego jako autorytetu intelektualnego i moralnego, zauważa jednak współczesną marginalizację jego twórczości - w okresie dominacji kultury masowej i konsump- 
cjonizmu. W konkluzji wszakże stwierdza z odrobiną optymizmu i nadziei:

Coraz częściej daje się $[\ldots]$ zauważyć znużenie i znudzenie papką pop-kultury. Więc może i Żeromski, wraz z całym wielkim kompleksem wartości, które uosabia jego pisarstwo - „nie wszystek umarl”? [Adamczyk, red. 2015: 459]

Te finałowe generalizacje podnoszą jeszcze wartość książki. Sformulowane przez badaczy wybitnych, uwypuklają istotne przecież składniki światopoglądu i metody twórczej Żeromskiego, a także cechy szeroko pojętej recepcji pisarza. Według mnie nie ulega wątpliwości trwałe miejsce recenzowanej monografii w najnowszej literaturze przedmiotu poświęconej Żeromskiemu. Jej zawartość tworzy bogata i zróżnicowana paleta egzegez, które odkrywają, reinterpretują, oświetlają choćby tak istotne wątki i motywy, jak między innymi: styl i poetyki pisarza, zagadnienie jego warsztatu twórczego, stosunek do sztuki filmowej, ideologia, wizja antropologiczno-kulturowa, odbiór w dwudziestoleciu międzywojennym, miejsce dzieł Żeromskiego w polskim życiu teatralnym, relacje z Rosją i rosyjskością etc.

\section{Bibliografia}

Adamczyk Zdzisław Jerzy, red. (2015), Stefan Żeromski. Kim byt? Kim jest? Materiały ogólnopolskiej konferencji naukowej Kielce 2-4 października 2014 r., słowo wstępne Andrzej Dąbrowski, panel konferencyjny i wypowiedzi panelowe zredagowała Grażyna Borkowska, Wojewódzka Biblioteka Publiczna im. Witolda Gombrowicza w Kielcach, Kielce.

Gabryś-Sławińska Monika, Olszewska Maria Jolanta (2015), Żeromski i inni, Wydawnictwo UMcs, Lublin.

Janicka Anna, Iwona E. Rusek, Czerwiński Grzegorz, red. (2014-2015), Żeromski. Piękno i wolność. Studia, idea i układ tomu Jarosław Ławski, Książnica Podlaska im. Ł. Górnickiego, Białystok-Rapperswil.

Olszewska Maria Jolanta (2015), Stefan Żeromski. Spotkania, Wydział Polonistyki Uniwersytetu Warszawskiego, Warszawa. 


\section{Tomasz Sobieraj}

\section{Stefan Żeromski. Identity, poetics and reception styles}

This article is a review of the collective monograph Stefan Żeromski. Kim byt? Kim jest? edited by Zdzisław Jerzy Adamczyk. The book contains thirty essays written by experts in their respective fields. Both Stefan Żeromski's views and many aspects of his writings were here thoroughly examined. It is said that Żeromski, one of the most influential Polish writers at the end of the nineteenth and at the beginning of the twentieth century, strongly affected Polish culture. The contributors of the book undoubtedly proved the thesis.

Keywords: Stefan Żeromski; reception; works.

Tomasz Sobieraj - profesor w Instytucie Filologii Polskiej UAM, historyk literatury drugiej połowy XIX w. Ostatnie publikacje książkowe: Polska krytyka i myśl teatralna w drugiej połowie XIX wieku. Studia i szkice (2014); W sprawie przełomu pozytywistycznego. Spory krytyczne wokót „Zarysu literatury polskiej z ostatnich lat szesnastu" Piotra Chmielowskiego (2015; współautor: Tadeusz Budrewicz), edycja krytyczna Emancypantek Bolesława Prusa (vol. 1, 2015). 